Canadian

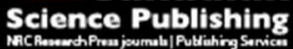

Canadian Journal of Microbiology Revue canadienne de de microbiologie

\title{
Effect of Bacoside A on growth and biofilm formation by Staphylococcus aureus and Pseudomonas aeruginosa
}

\begin{tabular}{|r|l|}
\hline Journal: & Canadian Journal of Microbiology \\
\hline Manuscript ID & cjm-2016-0365.R1 \\
\hline Danuscript Type: & Article \\
\hline Complete List of Authors: & $\begin{array}{l}\text { Parai, Debaprasad; University of Kalyani, Department of Microbiology } \\
\text { Islam, Ekramul; University of Kalyani, Department of Microbiology } \\
\text { Mitra, Jayati; Regional Institute of Ophthalmology, Department of } \\
\text { Pathology } \\
\text { Mukherjee, Samir Kumar; University of Kalyani, Department of } \\
\text { Microbiology }\end{array}$ \\
\hline Keyword: & $\begin{array}{l}\text { Bacoside A, Biofilm eradication, Extracellular polymeric substances, } \\
\text { Staphylococcus aureus, Pseudomonas aeruginosa }\end{array}$ \\
\hline
\end{tabular}

\section{SCHOLARONE"}

Manuscripts 
Title: Effect of Bacoside A on growth and biofilm formation by Staphylococcus aureus and Pseudomonas aeruginosa

Authors: Debaprasad Parai ${ }^{1}$, Ekramul Islam ${ }^{1}$, Jayati Mitra ${ }^{2}$ and Samir Kumar Mukherjee ${ }^{1 *}$

Address: ${ }^{1}$ Department of Microbiology, University of Kalyani, Kalyani 741235, India. ${ }^{2}$ Department of Pathology, Regional Institute of Ophthalmology, Kolkata 700073 India.

\section{Email addresses:}

Debaprasad Parai: debaprasad.bio@gmail.com

Ekramul Islam: ekramul.rs@gmail.com

Jayati Mitra: tanmayermail@gmail.com

Samir Kumar Mukherjee: dr.samirmukherjee@gmail.com

*Corresponding Author: Prof. Samir Kumar Mukherjee

Address for correspondence: Department of Microbiology, University of Kalyani, Kalyani 741235, India.

Email: dr.samirmukherjee@gmail.com

Tel: $+91-9433136617$

Fax: $+91-3325828282$ 
Effect of Bacoside A on growth and biofilm formation by Staphylococcus aureus and Pseudomonas aeruginosa

\author{
Debaprasad Parai ${ }^{1}$, Ekramul Islam $^{1}$, Jayati Mitra ${ }^{2}$ and Samir Kumar Mukherjee ${ }^{1 *}$ \\ ${ }^{1}$ Department of Microbiology, University of Kalyani, Kalyani 741235, India. \\ ${ }^{2}$ Department of Pathology, Regional Institute of Ophthalmology, Kolkata 700073, India
}

\begin{abstract}
The goal of this study was to evaluate the antibiofilm and antimicrobial activities of Bacoside A, a mixture formulation of phytochemicals from Bacopa monnieri against Staphylococcus aureus and Pseudomonas aeruginosa which are known to form biofilm as one of their virulence traits. The antimicrobial effects of Bacoside A were tested using the minimum inhibitory concentration (MIC) and minimum bactericidal concentration (MBC) assays. Cell membrane disruption assay was performed to find its possible target site. MTT assay, crystal violet assay and microscopic studies were performed to assess the antibiofilm activity. Bacoside A showed its antimicrobial activity against both the test organisms in their planktonic and biofilm states. It could significantly remove $\sim 88-93 \%$ bacterial biofilm developed on microtiter plate at sub-minimum inhibitory concentration of $200 \mu \mathrm{g} \mathrm{mL} L^{-1}$. Biochemical and microscopic studies suggested that the eradication of biofilm might be due to the loss of extracellular polymeric substances and change in cell membrane integrity of the selected bacterial strains treated with Bacoside A. These results indicate that Bacoside A might be considered as an antimicrobial having ability to disrupt biofilms, thus it could alone or in combination with other therapeutics be useful to treat biofilm related infections caused by opportunistic bacterial pathogens.
\end{abstract}

Keywords: Bacoside A; Biofilm eradication; Extracellular polymeric substances; Staphylococcus aureus; Pseudomonas aeruginosa 


\section{Introduction}

In most natural environments, microbes are commonly found in close association with surfaces and interfaces in the form of multicellular aggregates glued together with the slime they secrete. Biofilms are such clusters of microbial cells that are attached to a substratum like rock surfaces, living and dead plant or animal tissues, and synthetic polymers, ceramics and metal alloys by creating a protective matrix with extracellular polymeric substances (Stoodley et al. 2002; Hall-Stoodley et al. 2004). The mature biofilm could provide shelter by aggregating the bacteria, and thus protect them against desiccation, starvation and mechanical dispersion (Ahimou et al. 2007; Flemming et al. 2007). Extracellular polymeric substances (EPS) account the major proportion $(\sim 50-90 \%)$ of the total organic matter in a biofilm matrix (Vu et al. 2009). It has been suggested that EPS matrix protects bacteria from phagocytosis and opsonisation, and also prevents the access of antibiotics to the bacterial cells of the biofilm community and thus play a crucial role in human health (Costerton et al. 1999; Stephens 2002; Høibya et al. 2010). In fact, biofilm-associated bacterial infections are estimated to comprise more than $60 \%$ of all bacterial infections (Lewis 2001). Among the bacteria that are found to develop biofilm as one of the virulence factors, the Gram-negative bacterium Pseudomonas aeruginosa and Gram-positive bacterium Staphylococcus aureus have received most attention. $P$. aeruginosa is the most frequent cause of severe chronic infection in patients with cystic fibrosis whereas $S$. aureus are the most frequent causes of nosocomial infections on indwelling medical devices (Donlan 2001; Balasubramanian et al. 2013).

Due to the inappropriate use of conventional antibiotics and development of multidrug resistant (MDR) bacterial pathogenic strains, interest in natural products, notably phytochemicals, as alternative therapeutic agents is growing up (Cowan et al. 1999; Abreu et al. 2012). The major subclasses of phytochemicals are phenolics, alkaloids, terpenoids and 
other essential oils constituents, lectins and polypeptides, and polyacetylenes (Cowan 1999; Newman et al. 2000). These groups are well-documented for their antimicrobial properties when present in curcumin, reserpine, resveratrol, quercetin, andrographolides etc. (Hu et al. 2013; Dusane et al. 2014; Su et al. 2014; Wen et al. 2014).

Bacopa monnieri is a common herb found in tropical countries and has a long history as a medicinal plant (Singh and Dhawan 1997). Extract of B. monnieri has been reported to contain mainly alkaloids, tetracyclic triterpenoids, flavonoids, saponin, bacosides and phytosterols (Roodenrys et al. 2002). B. monnieri extract showed a variety of medicinal effects against anxiety, gastrointestinal discomfort, skin disorders, epilepsy, pyrexia and analgesia (Aguiar and Borowski 2013). It could be easily predicted that extract of B. monnieri might have enormous versatility of medicinal implementation though very little significant work has been done so far on its antimicrobial activity (Khan et al. 2010; Mathur et al. 2010; Emran et al. 2015). Bacoside A, known to be the main bioactive constituents of B. monnieri extract, is a mixture of bacoside A3, bacopaside II, bacopasaponin $\mathrm{C}$ and bacopaside $\mathrm{X}$, all are triterpenoid saponins having jujubogenin or pseudojujubogenin as their aglycone moiety (Ramasamy et al. 2015). Terpenoids have been reported to result in membrane disruption by interfering with the lipid moiety, thus alter membrane permeability which leads to the death of the treated bacteria (Trombetta et al. 2005; de León and Moujir 2008; Jasmine et al. 2011).

Considering the above background this article mainly focuses on the antimicrobial activity of Bacoside A on P. aeruginosa MTCC 2488 and S. aureus MTCC 96, two moderately pathogenic strains, targeting its effect on biofilm control.

\section{Materials and methods}

\section{Materials}

Nutrient Broth (NB), Brain-Heart Infusion (BHI) broth, Congo red and crystal violet dye were purchased from HiMedia, India. Sterilized flat bottomed 24 and 96 wells microtitre 
plates were procured from Tarsons, India. Absolute ethanol, HPLC grade methanol and glacial acetic acid were bought from Merck, India. Paraformaldehyde, Bacoside A, Dimethyl sulfoxide (DMSO) and 3-(4, 5-dimethyl-2-thiazolyl)-2, 5-diphenyl-2H-tetrazolium bromide (MTT) were purchased from Sigma-Aldrich, India. Circular glass coverslips (diameter 12 $\mathrm{mm}$; thickness $0.13-0.17 \mathrm{~mm}$ ) and $0.2 \mu \mathrm{m}$ RanDisc $^{\mathrm{TM}}$ syringe filters were bought from Blue StarC, India and Rankem, India, respectively.

\section{Bacterial strains and culture conditions}

Bacterial strains, Staphylococcus aureus MTCC 96 and Pseudomonas aeruginosa MTCC 2488 were obtained from Microbial Type Culture Collection and Gene Bank (MTCC), Chandigarh, India. Both these strains were featured as human pathogen and were of biosafety level 2 strains according to U.S. Public Health Service Guidelines. S. aureus MTCC 96 and P. aeruginosa MTCC 2488 were cultured in Brain-Heart Infusion (BHI) and Nutrient Broth (NB), repectively, at $37^{\circ} \mathrm{C}$ in an incubator with $180 \mathrm{rpm}$ mechanical shaking (MaxQ 6000, Thermo Scientific, Ohio, USA) to obtain $16 \mathrm{~h}$ grown cell suspension.

\section{Minimum inhibitory concentration of Bacoside A}

MIC of Bacoside A was determined against S. aureus MTCC 96 and P. aeruginosa MTCC 2488 following a standard microdilution protocol based on Clinical and Laboratory Standards Institute [CLSI] guidelines (Jorgensen and Ferraro 2009). Bacterial suspension of $20 \mu \mathrm{L}\left(\sim 5 \times 10^{5}\right.$ colony forming units $\left.[\mathrm{CFU}] \mathrm{mL}^{-1}\right)$ was inoculated in a 96 wells microtitre plate containing $200 \mu \mathrm{L}$ medium including varying concentrations $\left(50-600 \mu \mathrm{g} \mathrm{mL}^{-1}\right)$ of Bacoside A separately in each well and grown at $37^{\circ} \mathrm{C}$ for $24 \mathrm{~h}$ with $100 \mathrm{rpm}$ shaking. Positive control was prepared with cells in media without Bacoside A and negative control was set only with sterile broth, both having same proportions of $1 \%$ DMSO (v/v). Growth responses of the bacterial strains were determined after $24 \mathrm{~h}$ by measuring the optical density at $600 \mathrm{~nm}$ in a microtitre plate reader (Multiskan ${ }^{\circledR}$ EX, Thermo Scientific, Finland). MIC 
was defined as the lowest concentration of the antimicrobial compound that inhibited bacterial growth $\left(\mathrm{OD}_{600}<0.05\right)$ after $24 \mathrm{~h}$ of incubation at specified temperature. The incubated broth from each well that showed no growth was further inoculated onto agar plate without any antimicrobial and incubated at same temperature for $24 \mathrm{~h}$ to determine the minimum bactericidal concentration $(\mathrm{MBC})$ by drop method. $\mathrm{MBC}$ was defined as the lowest concentration that killed test bacteria. The MIC of Bacoside A for the test bacterial strains was calculated from three independent experiments, each having three replicas.

\section{Bacterial time-kill curves of Bacoside A}

Time-kill curves were obtained after treating S. aureus MTCC 96 and P. aeruginosa MTCC 2488 cells at their mid-log phase $\left(\mathrm{OD}_{600}=0.4\right)$ with $200 \mu \mathrm{g} \mathrm{mL} \mathrm{m}^{-1}$ Bacoside A. The concentration of $200 \mu \mathrm{g} \mathrm{mL}^{-1}$ was chosen as a sub-lethal concentration of Bacoside A after determining the MIC and MBC from the previous experiment. Untreated cell culture only with same proportions of $1 \%$ DMSO (v/v) was considered as control. Optical density of the culture was taken at 60 min intervals in a UV-Vis spectrophotometer (Evolution 201, Thermo Scientific, Austria). The viable cell number was calculated by counting the number of bacterial colonies developed on the plate and expressed as $\mathrm{CFU} \mathrm{mL} \mathrm{m}^{-1}$.

\section{Membrane damage assay}

To study the effect of the phytochemical on the bacterial cell membrane integrity, the membrane damage assay was performed by estimating the amount of nucleic acids released from the cell (Chen and Cooper 2002). Both bacterial strains were cultured in the respective liquid media as mentioned earlier by taking a loopfull of inoculum from the agar plate and incubated overnight. The culture was centrifuged at $5600 \times g$ for $10 \mathrm{~min}$, then the supernatant was discarded and the cell pellet was washed with $0.01 \mathrm{~mol} \mathrm{~L}^{-1}$ phosphate buffer saline (PBS, $\mathrm{pH}=7.4$ ) solution. Cell pellet was then re-suspended in respective liquid media in a way to set the optical density to 0.8 at $420 \mathrm{~nm}$ and the different concentrations $\left(50 \mu \mathrm{g} \mathrm{mL}^{-1}, 100 \mu \mathrm{g}\right.$ 
$\mathrm{mL}^{-1}$ and $200 \mu \mathrm{g} \mathrm{mL}^{-1}$ ) of Bacoside A was added to bacterial suspension. Control set was without Bacoside A, but with 1\% DMSO (v/v) as mentioned earlier. Two $\mathrm{mL}$ of sample was removed from each tube at 30 min intervals and immediately sieved with $0.2 \mu \mathrm{m}$ syringe filters to discard the bacterial cells. The released amount of DNA and RNA in the filtrate was measured at $260 \mathrm{~nm}$ in a UV-Vis spectrophotometer (Evolution 201, Thermo Scientific, Austria).

\section{Antibiofilm activity of Bacoside A}

\section{Scanning electron microscopy}

The effect of Bacoside A on the biofilm architecture was visualized by SEM images. Glass coverslips as biofilm substratum were sterilized with $\mathrm{NaOCl}$ solution $(0.5 \%, \mathrm{v} / \mathrm{v})$ and rinsed thoroughly with sterilized Milli-Q grade water. To initiate biofilm development, sterilized glass coverslips were immersed in 24 wells plate containing $1 \mathrm{~mL}$ of respective growth media. Media was inoculated with the respective bacterial cell suspension $\left(\mathrm{OD}_{600}=\right.$ $0.1)$ and incubated for $24 \mathrm{~h}$ at $37^{\circ} \mathrm{C}$ (Goswami et al. 2014). The developed bacterial biofilm were subsequently treated with $200 \mu \mathrm{g} \mathrm{mL}^{-1}$ of bacoside A and were incubated for another 24 $\mathrm{h}$ at $37^{\circ} \mathrm{C}$ under static condition. Control set was the biofilms treated only with same proportions of $1 \%$ DMSO $(\mathrm{v} / \mathrm{v})$. After $24 \mathrm{~h}$ of treatment, the media from the well was aspirated and the glass coverslips were washed with sterile PBS. Coverslips were then fixed with $2 \%$ freshly prepared depolymerized paraformaldehyde for $30 \mathrm{~min}$. Ultrapure paraformaldehyde powder was dissolved in PBS $\left(0.01 \mathrm{~mol} \mathrm{~L}^{-1}\right)$ and was subsequently heated at $55^{\circ} \mathrm{C}$ adding few drops of $10 \mathrm{~N}$ sodium hydroxide to get a clear solution of depolymerized paraformaldehyde. The coverslips were washed twice with $\mathrm{PBS}\left(0.01 \mathrm{~mol} \mathrm{~L}^{-1}\right)$ and dehydrated with increasing concentration series of ethanol $(50 \%, 60 \%, 70 \%, 80 \%, 90 \%$ and $100 \%$ ) for $10 \mathrm{~min}$ in each concentration (Kwieciński et al. 2009). Images were captured by Environmental Scanning Electron Microscope (EVO ${ }^{\circledR}$ LS 10, Zeiss, Germany) and analyzed 
by smartSEM Graphical User Interface software. The imaging conditions were with $5-10 \mathrm{kV}$ acceleration potential, 10-15 mm working distance, 50-100 pA probe current, and 6000X magnification.

\section{Biofilm quantification by crystal violet assay}

Biofilm biomass was quantified following the method of Stepanović et al. (2007). Bacterial cells were grown for $16 \mathrm{~h}$ in respective media, and $200 \mu \mathrm{L}$ culture of each bacterial strain was inoculated to $20 \mathrm{~mL}$ of media and incubated at $37^{\circ} \mathrm{C}$. Diluted $200 \mu \mathrm{L}$ bacterial cell suspension $\left(\mathrm{OD}_{600}=0.1\right)$ from mid-log phase of that culture was then added to a sterile flat bottom microtiter plate and incubated for $24 \mathrm{~h}$ to allow biofilm formation. After $24 \mathrm{~h}$ of incubation the used media was discarded from the wells and the respective fresh media containing different concentrations of Bacoside A $\left(50-200 \mu \mathrm{g} \mathrm{mL}^{-1}\right)$ were added to the wells maintaining three replicas for each treatment. Positive control was prepared with biofilm without Bacoside A and negative control was set only with sterile broth, both having same proportions of $1 \%$ DMSO $(\mathrm{v} / \mathrm{v})$. The plate was subsequently incubated at $37^{\circ} \mathrm{C}$ for another 24 $\mathrm{h}$ under static condition. The content of the each well was aspirated and wells were vigorously shaken with $200 \mu \mathrm{L}$ PBS $\left(0.01 \mathrm{~mol} \mathrm{~L}^{-1}\right)$ to wash out all non-adherent bacteria. The remaining attached bacteria were fixed with $200 \mu \mathrm{l}$ of methanol for $15 \mathrm{~min}$. The plates were then stained with $200 \mu \mathrm{L}$ of $2 \%$ crystal violet for $5 \mathrm{~min}$ at room temperature. Biofilm matrices on the plate surface were slowly rinsed thrice by submerging the plate in a tub of sterile de-ionized water. The microtiter plate was left to dry at room temperature for $60 \mathrm{~min}$ by placing it upside down on a stack of tissue paper. The dye bound to the adherent cells was re-solubilized with $200 \mu \mathrm{L}$ of $33 \%$ (v/v) glacial acetic acid and the solubilised dye was transferred to a new microtiter plate. Absorbance was measured at $570 \mathrm{~nm}$ in a microtiter plate reader (Multiskan ${ }^{\circledR}$ EX, Thermo Scientific, Finland). All assays were performed in triplicates. 


\section{Biofilm viability test by MTT assay}

S. aureus MTCC 96 and P. aeruginosa MTCC 2488 were grown overnight in a sterile 96 wells microtiter plate to develop biofilm (Müsken et al. 2010) and then different concentrations (50-200 $\mu \mathrm{g} \mathrm{mL} \mathrm{m}^{-1}$ ) of Bacoside A was added following the method as described in crystal violet assay. Positive and negative control sets were prepared as described earlier. The spent media was dispensed from the wells and washed with PBS to remove planktonic bacteria. The wells were air dried and $200 \mu \mathrm{L}$ fresh media with MTT reagent $\left(0.5 \mathrm{mg} \mathrm{mL}^{-1}\right)$ was added to each well of the microtitre plate and incubated in dark for $2 \mathrm{~h}$ at $37^{\circ} \mathrm{C}$. After incubation the MTT solution was discarded and immediately $200 \mu \mathrm{L}$ of DMSO was added to the wells to solubilize the formazan crystals formed in the wells, mixed thoroughly and left for $15 \mathrm{~min}$ incubation period at $25^{\circ} \mathrm{C}$ (Saising et al. 2012). At the end of incubation the absorbance of the solution was measured at a wavelength of $570 \mathrm{~nm}$ using a microtiter plate reader (Multiskan ${ }^{\circledR}$ EX, Thermo Scientific, Finland). All assays were performed in triplicates.

\section{Congo red staining for qualitative estimation of extracellular polymeric substances}

$S$. aureus MTCC 96 and $P$. aeruginosa MTCC 2488 biofilm were grown overnight in sterile 24 wells plate containing circular glass coverslips as described earlier. The developed bacterial biofilm were subsequently treated with $200 \mu \mathrm{g} \mathrm{mL} \mathrm{m}^{-1}$ of bacoside A and were incubated for another $24 \mathrm{~h}$ at $37^{\circ} \mathrm{C}$ under static condition. Biofilm treated only with $1 \%$ DMSO was considered as control. Coverslips were taken out of the wells and washed with PBS $\left(0.01 \mathrm{~mol} \mathrm{~L}^{-1}\right)$ to remove non-adherent substances or planktonic cells and were air dried. The cover slips were then stained with $20 \mu \mathrm{L}$ of $1 \%$ Congo red under dark for $30 \mathrm{~min}$ and observed under fluorescence microscope (Motic BA410, Hong Kong) at 490 nm (Goswami et al. 2014). 
A confocal laser scanning microscope (Leica TCS SP8, Leica Microsystems, Germany) was used to acquire images of biofilms samples following a standard protocol (Jeon et al. 2009). Samples were prepared following the steps as mentioned in fluorescemce microscopy. Images were recorded at an excitation wavelength of $488 \mathrm{~nm}$ and an emission wavelength of $600-630 \mathrm{~nm}$ by detection of the fluorescence from Congo red. Image stacks through $\mathrm{Z}$ axis were collected from random points of the biofilms and analyzed by Leica Application Suite X (LAS X) software to get a 3D view of the biofilm matrix.

\section{Statistical analysis}

Descriptive statistical analyses were performed using GraphPad Prism version 5.00 (GraphPad Software, San Diego, USA) considering each set as one treatment regime with three replications including respective control set. The data are presented as mean \pm standard deviation (SD). Intergroup differences were calculated using analysis of variance (ANOVA). $P$ value of $<0.05$ was considered statistically significant.

\section{Results}

\section{Determination of antibacterial activity of Bacoside A}

Bacoside A was found to inhibit the growth of both strains within the concentration range of $100-600 \mu \mathrm{g} \mathrm{mL}^{-1}$. It was observed that $100 \mu \mathrm{g} \mathrm{mL}^{-1}$ ceased $\sim 50 \%$ of the bacterial growth, and above $200 \mu \mathrm{g} \mathrm{mL} \mathrm{mL}^{-1}$ concentration, growth was completely ceased but killed $\sim 90 \%$ of cells (Fig. 1a), which corroborated with earlier findings on S. aureus (Emran et al. 2015). Thus $200 \mu \mathrm{g} \mathrm{mL}^{-1}$ was considered as the sub-MIC value for the further investigations. The MBC was recorded as $400 \mu \mathrm{g} \mathrm{mL}^{-1}$ where not a single viable colony was obtained on agar plate. The time-kill curves of Bacoside A against both $S$. aureus MTCC 96 and $P$. aeruginosa MTCC 2488 are presented in Fig. 1b to show the cessation of growth of both the strains upon treatment.

\section{Effect of Bacoside A on bacterial membrane}


In many instances membrane serves as the architectural support for protecting the cell against any biocidal challenge (Chen and Cooper 2002). Thus, measuring the release of intracellular components would be a good parameter to assess damage in membrane integrity, if any. In this study, damage in membrane integrity for both the strains was increased with the increasing concentration of Bacoside A and its exposure time (Fig. 2). As a result, absorbance $\left(\mathrm{A}_{260}\right)$ of the released intracellular components, mostly nucleic acids, increased in the treated sets for both the bacterial strains.

\section{Antibiofilm activity of Bacoside A}

\section{Scanning Electron Microscopic study}

The control cells of $S$. aureus MTCC 96 showed matured biofilm with multilayered cells along with densely cell-cell attachment as visualized in SEM images (Fig. 3a). But the Bacoside A treated cells were found to lose such attachments and allocated into small discrete clusters (Fig. 3b). Evidence of significant eradication of $P$. aeruginosa MTCC 2488 biofilm was also established by the SEM images when treated with $200 \mu \mathrm{g} \mathrm{mL} \mathrm{L}^{-1}$ of Bacoside A. The treated cells showed shrinkage, apparent surface smoothness disruption and loss of cell-cell adhesion (Fig. 3d). On the other hand, control set showed organized cluster of pseudomonad cells (Fig. 3c).

\section{Crystal violet and MTT assay for studying biofilm eradication}

Crystal violet assay suggested that treatment of $S$. aureus MTCC 96 and $P$. aeruginosa MTCC 2488 with Bacoside A resulted in removal of biofilm formed by those strains (Fig. 4). Dispersion of biofilm increased with increasing Bacoside A concentration and it achieved $\sim 90 \%$ in both the strains when treated with sub-MIC dose $\left(200 \mu \mathrm{g} \mathrm{mL}^{-1}\right)$. Results from MTT assay showed that the percentage of viable bacterial cells within biofilm declined with increasing dose of Bacoside A (Fig. 5). It is significantly declined to $\sim 10 \%$ in comparison to the positive control set for both the strains when treated with sub-MIC dose. 
ANOVA analysis also suggested that both the data at $200 \mu \mathrm{g} \mathrm{mL} L^{-1}$ were significant $(P<$ 0.001) compared to positive control.

\section{Microscopic study of biofilm matrix}

The function of the EPS matrix is to provide cohesion between bacterial cells, thus securing the formation of a well structured biofilm. Fluorescence images of Congo red stained biofilm showed a notable loss of EPS matrix network eventually the adherence both in S. aureus MTCC 96 and P. aeruginosa MTCC 2488 after Bacoside A treatment (Fig. 6). Similar results were found in CSLM images, which showed the changes in topography of the developed biofilm when treated with $200 \mu \mathrm{g} \mathrm{mL} \mathrm{L}^{-1}$ of Bacoside A for both $S$. aureus MTCC 96 and P. aeruginosa 2488 (Fig. 7a-d). LAS X software analysis showed that the average thickness of $S$. aureus biofilm was higher than that formed by P. aeruginosa (Fig. 7a, c) in untreated regime, however, upon treatment remnant biofilm showed nearly same thickness $(\sim 2 \mu \mathrm{m})$ for both the strains (Fig. $7 \mathrm{~b}, \mathrm{~d})$.

\section{Discussion}

Emergence of antibiotic resistance in planktonic bacteria and of their biofilm counterpart is currently guiding the interest of researchers towards alternative drug sources, mostly from immense natural diversity (Abreu et al. 2012; Taylor 2013). Primarily the secondary metabolites from the plants have shown the antimicrobial effects and are being used as a major source of drugs having minor or no side effects (Newman and Cragg 2012). In this study, Bacoside A has shown its potential as an antimicrobial and antibiofilm agent against two most opportunistic pathogenic bacteria entities of human concern, namely $S$. aureus and $P$. aeruginosa. The test phytochemical could eliminate a good percentage of bacterial biofilm of those selected bacterial strains from the biofilm substratum. Bacoside A could be considered as an effective antimicrobial agent as it gave the MIC value $<400 \mu \mathrm{g}$ $\mathrm{mL}^{-1}$ (Simões et al. 2009). Qualitatively SEM images suggested high eradication of bacterial 
biofilm after treating with Bacoside $\mathrm{A}$, which was quantitatively determined by crystal violet assay. MTT assay further established the mortality percentage of bacterial cells within a treated biofilm.

Triterpenoid saponin might have a role in alteration of membrane permeability when it comes in contact with bacterial membrane lipids and thus helps to create a channel for the following treated drugs (Trombetta et al. 2005; Arabski et al. 2009). Here, damage of cell membrane might be due to the detergent-like activity of saponin present in Bacoside A, which was hypothesized by several earlier studies on antimicrobial and anti-biofilm properties of other plant saponins (Khanna et al. 2008; Sadowska et al. 2014; Ye et al. 2015).

An essential requirement to develop mature biofilm is cell-cell cohesion as well as high cell density (Costerton et al. 1999). In addition, EPS has a very important role in the biofilm-mode of bacterial life as it aids intense interaction and more persistency to the biofilm cells (Høibya et al. 2010). SEM, fluorescence microscopy and CLSM images revealed the loss of such phenomena including changes in cell morphology when the mature biofilms were treated with Bacoside A. Congo red staining of Bacoside A treated sample showed a clear evidence of biofilm dispersion due to loss of EPS. Earlier reports also suggested EPS production inhibition lead to eradication of bacterial biofilm (Pandit et al. 2015). So, Bacoside A might play another role through the loss of EPS component which eventually lead to the dispersion of bacterial biofilm. Such observations were also documented earlier with terpenoids and saponins against mature candida biofilm (Pires et al. 2011; Sadowska et al. 2014).

Thus it could be concluded that Bacoside A has both antimicrobial and antibiofilm effects on S. aureus MTCC 96 and P. aeruginosa MTCC 2488. This phytochemical might alter the bacterial cell membrane permeability and interact with intracellular components in planktonic stage. Within a mature biofilm it could detach and disperse bacterial cells from the 
substratum. Although there are many reports available on the antimicrobial properties of plants extracts, very little research has been done so far on the antibacterial and antibiofilm activities of Bacoside A. This is the first report on the antibiofilm activity of Bacoside A against such opportunistic bacterial pathogens. Considering the activity of Bacoside A against pathogenic bacterial strains, it shows a promise in the perspective of new antibacterial drug development.

\section{Acknowledgement}

Authors acknowledge the support received from University of Kalyani under DSTPURSE programme, Govt. of India, India and Fellowship grant from University Grants Commission, India.

\section{REFERENCES}

Abreu, A.C., McBain, A.J., and Simões, M. 2012. Plants as sources of new antimicrobials and resistance modifying agents. Nat. Prod. Rep. 29(9): 1007-1021.

Aguiar, S., and Borowski, T. 2013. Neuropharmacological review of the nootropic herb Bacopa monnieri. Rejuvenation Res. 16(4): 313-326.

Ahimou, F., Semmens, M.J., Haugstad, G., and Novak, P.J. 2007. Effect of protein, polysaccharide, and oxygen concentration profiles on biofilm cohesiveness. Appl. Environ. Microbiol. 73(9): 2905-2910.

Arabski, M., Wąsik, S., Dworecki, K., and Kaca, W. 2009. Laser interferometric and cultivation methods for measurement of colistin/ ampicilin and saponin interactions with smooth and rough of Proteus mirabilis lipopolysaccharides and cells. J. Microbiol. Methods. 77(2): 178-183.

Balasubramanian, D., Schneper, L., Kumari, H., and Mathee, K. 2013. A dynamic and intricate regulatory network determines Pseudomonas aeruginosa virulence. Nucleic Acids Res. 41(1): 1-20. 
Chen, C.Z., and Cooper, S.L. 2002. Interactions between dendrimer biocides and bacterial membranes. Biomaterials. 23(16): 3359-3368.

Costerton, J.W., Stewart, P.S., and Greenberg, E.P. 1999. Bacterial biofilms: a common cause of persistent infections. Science. 284(5418): 1318-1322.

Cowan, M.M. 1999. Plant products as antimicrobial agents. Clin. Microbiol. Rev. 12(4): 564 582.

de León, L., and Moujir, L. 2008. Activity and mechanism of the action of zeylasterone against Bacillus subtilis. J. Appl. Microbiol. 104(5): 1266-1274.

Donlan, R.M. 2001. Biofilms and device-associated infections. Emerg. Infect. Dis. 7(2): 277281.

Dusane, D.H., Hosseinidoust, Z., Asadishad, B., and Tufenkji, N. 2014. Alkaloids modulate motility, biofilm formation and antibiotic susceptibility of uropathogenic Escherichia coli. PLoS ONE. 9(11): e112093.

Emran, T.B., Rahman, M.A., Uddin, M.M.N., Dash, R., Hossen, M.F., Mohiuddin, M., and Alam, M.R. 2015. Molecular docking and inhibition studies on the interactions of Bacopa monnieri's potent phytochemicals against pathogenic Staphylococcus aureus. Daru J. Pharm. Sci. 23: 26.

Flemming, H-C., Neu, T.R., and Wozniak, D.J. 2007. The EPS matrix: The "house of biofilm cells”. J. Bacteriol. 189(22): 7945-7947.

Goswami, S., Thiyagarajan, D., Das, G., and Ramesh, A. 2014. Biocompatible nanocarrier fortified with a dipyridinium-based amphiphile for eradication of biofilm. ACS Appl. Mater. Interfaces. 6(18): 16384-16394.

Hall-Stoodley, L., Costerton, J.W., and Stoodley, P. 2004. Bacterial biofilms: from the natural environment to infectious diseases. Nat. Rev. Microbiol. 2(2): 95-108. 
Høibya, N., Bjarnsholta, T., Givskov, M., Molin, S., and Ciofu, O. 2010. Antibiotic resistance of bacterial biofilms. Int. J. Antimicrob. Agents. 35(4): 322-332.

Hu, P., Huang, P., and Chen, M.W. 2013. Curcumin reduces Streptococcus mutans biofilm formation by inhibiting sortase A activity. Arch. Oral. Biol. 58(10): 1343-1348.

Jasmine, R., Selvakumar, B.N., and Daisy, P. 2011. Investigating the mechanism of action of terpenoids and the effect of interfering substances on an Indian medicinal plant extract demonstrating antibacterial activity. IJPSR. 2(2): 19-24.

Jeon, J.G., Klein, M.I., Xiao, J., Gregoire, S., Rosalen, P.L., and Koo, H. 2009. Influences of naturally occurring agents in combination with fluoride on gene expression and structural organization of Streptococcus mutans in biofilms. BMC Microbiol. 9: 228.

Jorgensen, J.H., and Ferraro, M.J. 2009. Antimicrobial susceptibility testing: a review of general principles and contemporary practices. Clin. Infect. Dis. 49(11): 1749-1755.

Khan, A.V., Ahmed, Q.U., Shukla, I., and Khan, A.A. 2010. Antibacterial efficacy of Bacopa monnieri leaf extracts against pathogenic bacteria. Asian Biomed. 4(4): 651-655.

Khanna, V.G., and Kannabiran, K. 2008. Antimicrobial activity of saponin fractions of the leaves of Gymnema sylvestre and Eclipta prostrata. World J. Microbiol. Biotechnol. 24: $2737-2740$.

Kwieciński, J., Eick, S., and Wójcik, K. 2009. Effects of tea tree (Melaleuca alternifolia) oil on Staphylococcus aureus in biofilms and stationary growth phase. Int. J. Antimicrob. Agents. 33: 343-347.

Lewis, K. 2001. Riddle of biofilm resistance. Antimicrob. Agents. Chemother. 45(4): 9991007.

Mathur, A., Verma, S.K., Purohit, R., Singh, S.K., Mathur, D., Prasad, G.B.K.S., and Dua, V.K. 2010. Pharmacological investigation of Bacopa monnieri on the basis of 
antioxidant, antimicrobial and anti-inflammatory properties. J. Chem. Pharm. Res. 2(6): 191-198.

Müsken, M., Fiore, S.D., Römling, U., and Häussler, S. 2010. A 96-well-plate-based optical method for the quantitative and qualitative evaluation of Pseudomonas aeruginosa biofilm formation and its application to susceptibility testing. Nat. Protocols. 5(8): 1460-1469.

Newman, D.J., and Cragg, G.M. 2012. Natural products as sources of new drugs over the 30 years from 1981 to 2010. J. Nat. Prod. 75(3): 311-335.

Newman, D.J., Cragg, G.M., and Snader, K.M. 2000. The influence of natural products upon drug discovery. Nat. Prod. Rep. 17: 215-234.

Pandit, S., Cai, J.N., Song, K.Y., and Jeon, J.G. 2015. Identification of anti-biofilm components in Withania somnifera and their effect on virulence of Streptococcus mutans biofilms. J. Appl. Microbiol. 119(2): 571-581.

Pires, R.H., Montanari, L.B., Martins, C.H., Zaia, J.E., Almeida, A.M., Matsumoto, M.T., and Mendes-Giannini, M.J. 2011. Anticandidal efficacy of cinnamon oil against planktonic and biofilm cultures of Candida parapsilosis and Candida orthopsilosis. Mycopathologia. 172(6): 453-464.

Ramasamy, S., Chin, S.P., Sukumaran, S.D., Buckle, M.J.C., Kiew, L.V., and Chung, L.Y. 2015. In silico and in vitro analysis of bacoside A aglycones and its derivatives as the constituents responsible for the cognitive effects of Bacopa monnieri. PLoS ONE. 10(5): e0126565.

Roodenrys, S., Booth, D., Bulzomi, S., Phipps, A., Micallef, C., and Smoker, J. 2002. Chronic effects of Brahmi (Bacopa monnieri) on human memory. Neuropsychopharmacology. 27(2): 279-281. 
Sadowska, B., Budzyńska, A., Więckowska-Szakiel, M., Paszkiewicz, M., Stochmal, A., Moniuszko-Szajwaj, B., Kowalczyk, M., and Różalska, B. 2014. New pharmacological properties of Medicago sativa and Saponaria officinalis saponin-rich fractions addressed to Candida albicans. J. Med. Microbiol. 63: 1076-1086.

Saising, J., Dube, L., Ziebandt, A-K., Voravuthikunchai, S.P., Nega, M., and Götz, F. 2012. Activity of gallidermin on Staphylococcus aureus and Staphylococcus epidermidis biofilms. Antimicrob. Agents. Chemother. 56(11): 5804-5810.

Simões, M., Bennett, R.N., and Rosa, E.A.S. 2009. Understanding antimicrobial activities of phytochemicals against multidrug resistant bacteria and biofilms. Nat. Prod. Rep. 26(6): 746-757.

Singh, H.K., and Dhawan, B.N. 1997. Neuropsychopharmacological effects of the ayurvedic nootropic Bacopa monniera Linn. (Brahmi). Indian J. Pharmacol. 29(5): 359-365.

Stepanović, S., Vuković, D., Hola, V., Bonaventura, G.D., Djukić, S., Irković, I., and Ruzicka, F. 2007. Quantification of biofilm in microtiter plates: overview of testing conditions and practical recommendations for assessment of biofilm production by staphylococci. APMIS. 115(8): 891-899.

Stephens, C. 2002. Microbiology: breaking down biofilms. Curr. Biol. 12: R132-R134.

Stoodley, P., Sauer, K., Davies, D.G., and Costerton, J.W. 2002. Biofilm as complex differentiated communities. Annu. Rev. Microbiol. 56: 187-209.

Su, Y., Ma, L., Wen, Y., Wang, H., and Zhang, S. 2014. Studies of the in vitro antibacterial activities of several polyphenols against clinical isolates of methicillin-resistant Staphylococcus aureus. Molecules. 19(8): 12630-12639.

Taylor, P.W. 2013. Alternative natural sources for a new generation of antibacterial agents. Int. J. Antimicrob. Agents. 42(3): 195-201. 
Trombetta, D., Castelli, F., Sarpietro, M.G., Venuti, V., Cristani, M., Daniele, C., Saija, A., Mazzanti, G., and Bisignano, G. 2005. Mechanisms of antibacterial action of three monoterpenes. Antimicrob. Agents. Chemother. 49(6): 2474-2478.

Vu, B., Chen, M., Crawford, R.J., and Ivanova, E.P. 2009. Bacterial extracellular polysaccharides involved in biofilm formation. Molecules. 14(7): 2535-2554.

Ye, Y., Yang, Q., Fang, F., and Li, Y. 2015. The camelliagenin from defatted seeds of Camellia oleifera as antibiotic substitute to treat chicken against infection of Escherichia coli and Staphylococcus aureus. BMC Vet. Res. 11: 214. 


\section{Legends of Figures}

Fig. 1. Antibacterial effect of Bacoside A on planktonic cells of $S$. aureus MTCC 96 and P. aeruginosa MTCC 2488. (a) MIC of Bacoside A after $24 \mathrm{~h}$ of incubation; growth responses presented as a measure of OD value at $600 \mathrm{~nm}$ at different concentrations. Data are the mean of three replicas with \pm SD. (b) Time-kill curve [viable cell number versus treatment time] of the test bacterial strains treated at mid-log phase with $200 \mu \mathrm{g} \mathrm{mL} \mathrm{m}^{-1}$ Bacoside A and compared with untreated cells. Data are the mean of three replicas with \pm SD bars. ${ }^{*}=P<$ $0.05 ; * * *=P<0.001 ; \bullet=P<0.01 ; \cdots=P<0.001$ : significant compared with respective controls.

Fig. 2. Effect of Bacoside A on cell membrane. Release of intracellular materials, targeting nucleic acids, from treated cells of (a) S. aureus MTCC 96 and (b) P. aeruginosa MTCC 2488 with the function of time as a measure of absorbance at $260 \mathrm{~nm}$. In both cases cells were treated with different concentrations of Bacoside A. Data are the mean of three replicas with \pm SD bars. $*=P<0.05 ; * *=P<0.01 ; * * *=P<0.001$ : significant compared with respective controls.

Fig. 3. Scanning electron microscopy (SEM) images of biofilm. (a) Control and (b) treated biofilm of S. aureus MTCC 96; (c) Control and (d) treated biofilm of P. aeruginosa MTCC 2488. For both the strains, treatment was done with $200 \mu \mathrm{g} \mathrm{mL}^{-1}$ Bacoside A for $24 \mathrm{~h}$ and control biofilms were incubated with 1\% DMSO for $24 \mathrm{~h}$. Scale bar represents $2 \mu \mathrm{m}$.

Fig. 4. Effect of Bacoside $A$ on bacterial biofilm as measured by crystal violet assay. Biofilm eradication percentage compared to respective positive control in (a) S. aureus MTCC 96, and (b) P. aeruginosa MTCC 2488. In both the strains, developed biofilms were treated with different concentrations of Bacoside A for $24 \mathrm{~h}$ or 1\% DMSO as positive control. Data are the mean of three replicas with \pm SD bars. $* * *=P<0.001$ : significant compared with respective controls.

Fig. 5. Viability assay of preformed biofilm cells treated with Bacoside A. Percentage of cell viability compared to respective positive control, (a) S. aureus MTCC 96 and (b) $P$. aeruginosa MTCC 2488. The developed biofilms were treated with different concentrations of Bacoside A for $24 \mathrm{~h}$ or $1 \%$ DMSO as positive control; cell viability was determined by MTT assay. Data are the mean of three replicas with \pm SD bars. $* *=P<0.01 ; * * *=P<$ 0.001: significant compared with respective controls.

Fig. 6. Congo red stained fluorescence microscope images of biofilm. The biofilm was treated for $24 \mathrm{~h}$ either with $200 \mu \mathrm{g} \mathrm{mL}^{-1}$ Bacoside A or 1\% DMSO as control and then the 
biofilm matrix was stained with $1 \%$ Congo red. (a) Control and (b) treated biofilm of $S$. aureus MTCC 96; (c) Control and (d) treated biofilm of $P$. aeruginosa MTCC 2488. Scale bar represents $25 \mu \mathrm{m}$.

Fig. 7. CLSM of bacterial biofilm before and after Bacoside A treatment. The developed biofilm was treated for $24 \mathrm{~h}$ with $200 \mu \mathrm{g} \mathrm{mL}^{-1}$ Bacoside A or 1\% DMSO as control and then the biofilm matrix was stained with $1 \%$ Congo red for CLSM image analysis. (a) Control and (b) treated biofilm of $S$. aureus MTCC 96; (c) Control and (d) treated biofilm of $P$. aeruginosa MTCC 2488. All four images have two separate views- oblique 3D view (shown in upper part) and vertical view (shown in lower part). 


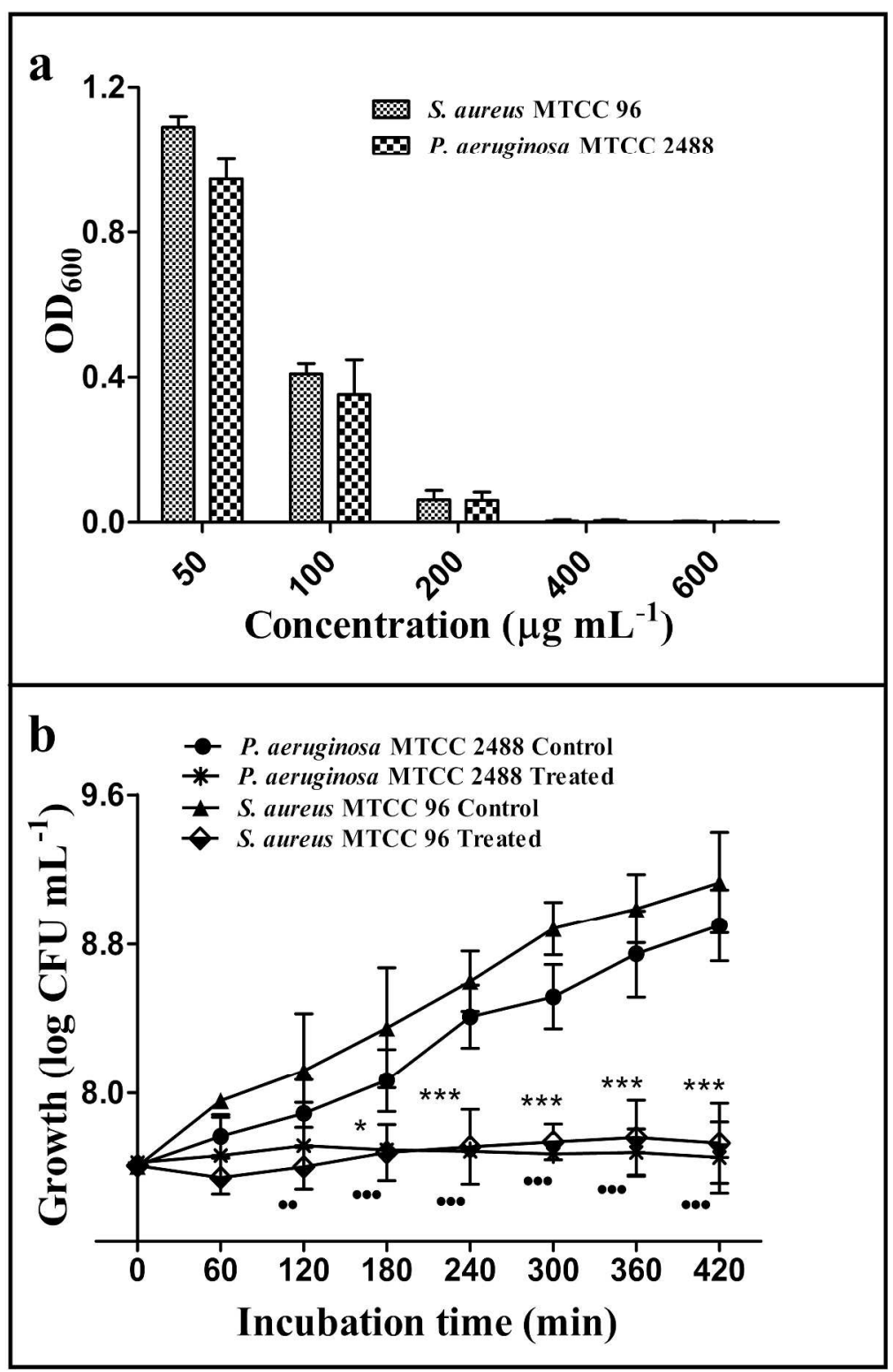

Fig. 1. Antibacterial effect of Bacoside A on planktonic cells of S. aureus MTCC 96 and P. aeruginosa MTCC 2488. (a) MIC of Bacoside A after $24 \mathrm{~h}$ of incubation; growth responses presented as a measure of OD value at $600 \mathrm{~nm}$ at different concentrations. Data are the mean of three replicas with $\pm S D$. (b) Time-kill curve [viable cell number versus treatment time] of the test bacterial strains treated at mid-log phase with $200 \mu \mathrm{g}$ $\mathrm{mL}-1$ Bacoside $\mathrm{A}$ and compared with untreated cells. Data are the mean of three replicas with \pm SD bars. $*=$ $\mathrm{P}<0.05 ; * * *=\mathrm{P}<0.001 ; \bullet=\mathrm{P}<0.01 ; \bullet \bullet=\mathrm{P}<0.001$ : significant compared with respective controls. Fig. 1.

$127 \times 192 \mathrm{~mm}(600 \times 600 \mathrm{DPI})$ 


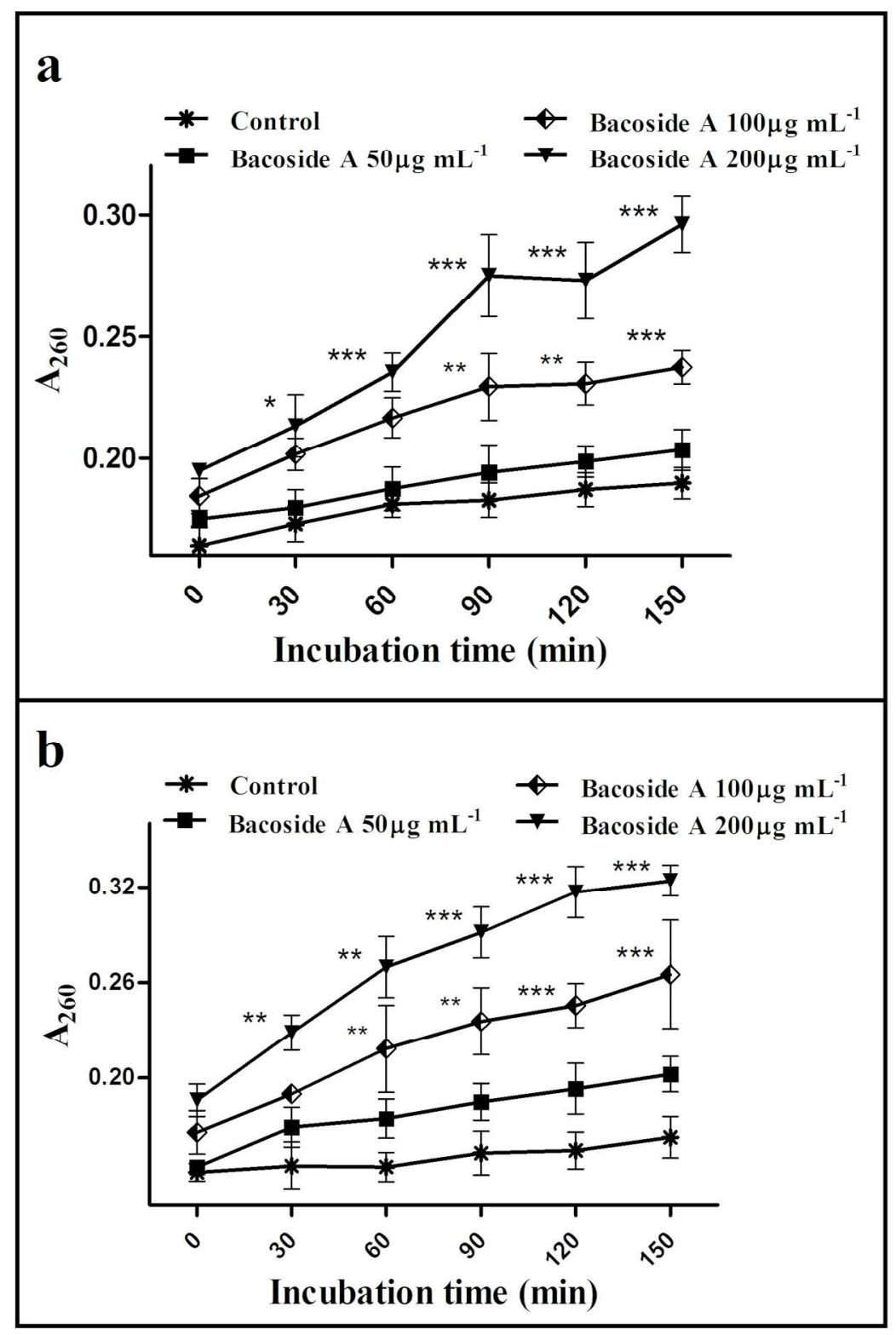

Fig. 2. Effect of Bacoside A on cell membrane. Release of intracellular materials, targeting nucleic acids, from treated cells of (a) S. aureus MTCC 96 and (b) P. aeruginosa MTCC 2488 with the function of time as a measure of absorbance at $260 \mathrm{~nm}$. In both cases cells were treated with different concentrations of Bacoside

A. Data are the mean of three replicas with \pm SD bars. $*=\mathrm{P}<0.05 ; * *=\mathrm{P}<0.01 ; * * *=\mathrm{P}<0.001$ : significant compared with respective controls.

Fig. 2.

$95 \times 142 \mathrm{~mm}(600 \times 600$ DPI $)$ 


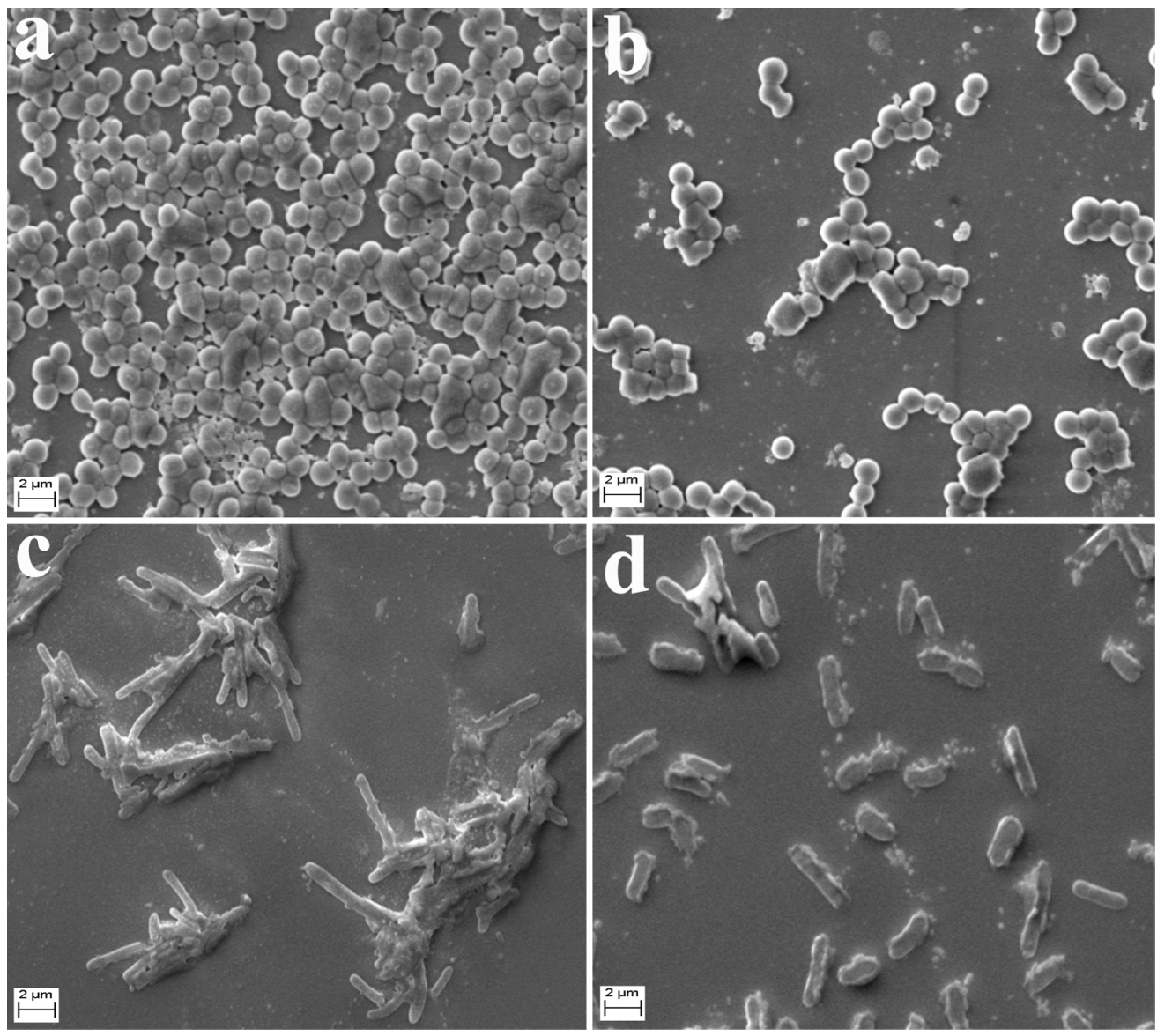

Fig. 3. Scanning electron microscopy (SEM) images of biofilm. (a) Control and (b) treated biofilm of S. aureus MTCC 96; (c) Control and (d) treated biofilm of P. aeruginosa MTCC 2488. For both the strains, treatment was done with $200 \mu \mathrm{g} \mathrm{mL}-1$ Bacoside $\mathrm{A}$ for $24 \mathrm{~h}$ and control biofilms were incubated with $1 \%$ DMSO for $24 \mathrm{~h}$. Scale bar represents $2 \mu \mathrm{m}$.

Fig. 3.

$166 \times 148 \mathrm{~mm}(300 \times 300 \mathrm{DPI})$ 


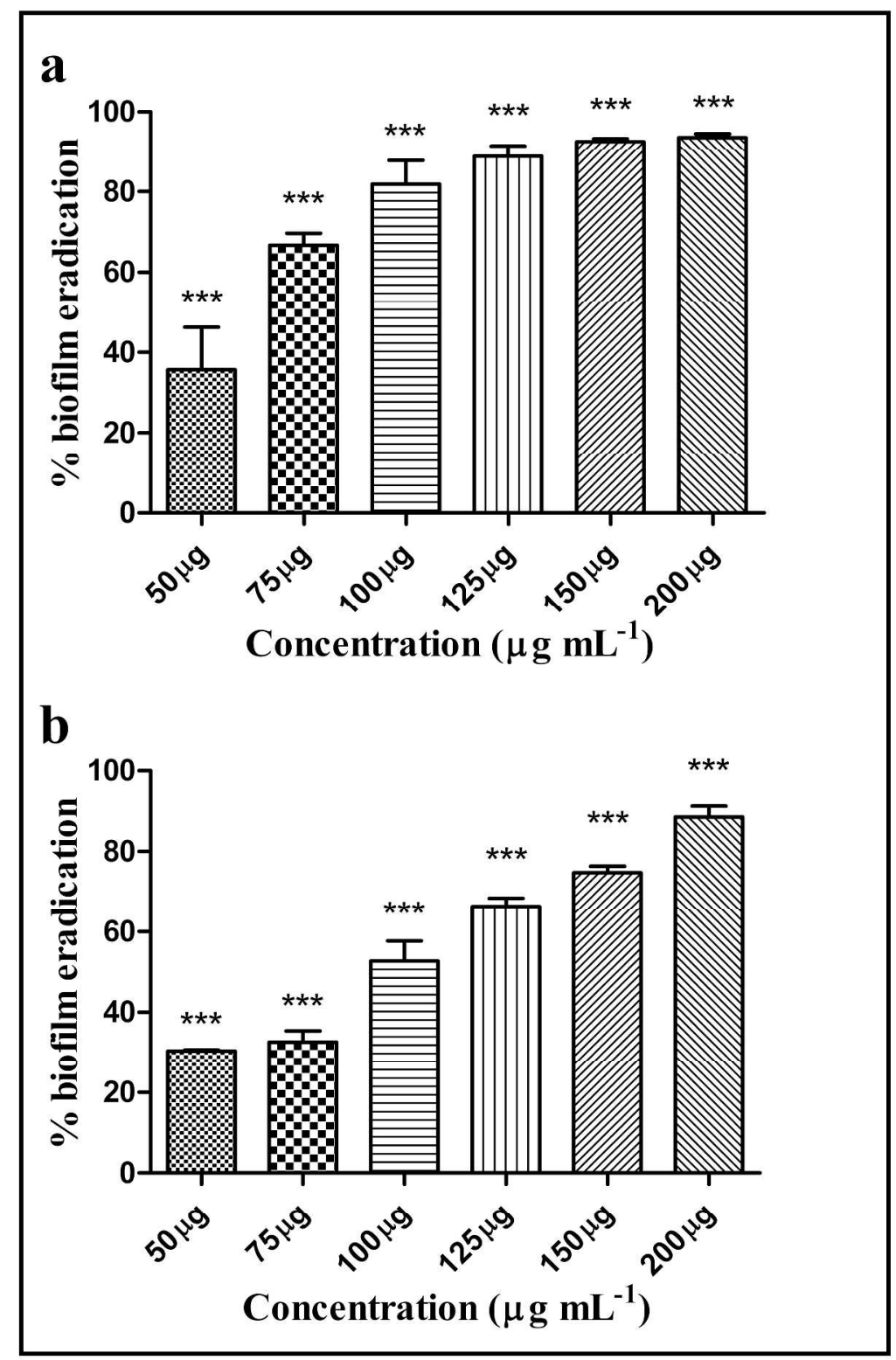

Fig. 4. Effect of Bacoside A on bacterial biofilm as measured by crystal violet assay. Biofilm eradication percentage compared to respective positive control in (a) S. aureus MTCC 96, and (b) P. aeruginosa MTCC 2488. In both the strains, developed biofilms were treated with different concentrations of Bacoside A for 24 $\mathrm{h}$ or $1 \%$ DMSO as positive control. Data are the mean of three replicas with \pm SD bars. $* * *=\mathrm{P}<0.001$ : significant compared with respective controls.

Fig. 4.

$127 \times 192 \mathrm{~mm}(600 \times 600 \mathrm{DPI})$ 


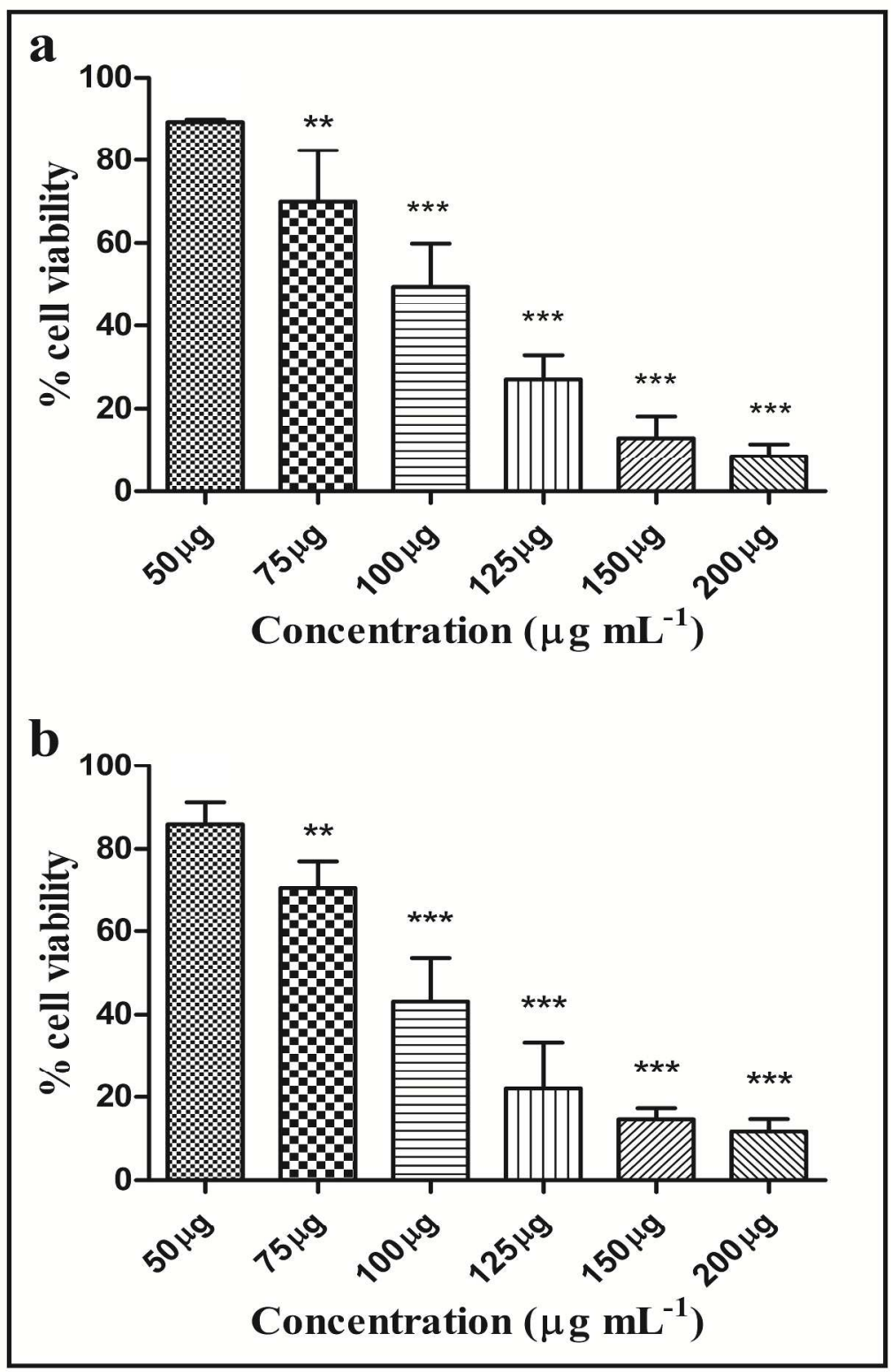

Fig. 5. Viability assay of preformed biofilm cells treated with Bacoside A. Percentage of cell viability compared to respective positive control, (a) S. aureus MTCC 96 and (b) P. aeruginosa MTCC 2488. The developed biofilms were treated with different concentrations of Bacoside A for $24 \mathrm{~h}$ or $1 \%$ DMSO as positive control; cell viability was determined by MTT assay. Data are the mean of three replicas with \pm SD bars. ** $=\mathrm{P}<0.01 ; * * *=\mathrm{P}<0.001$ : significant compared with respective controls.

Fig. 5 .

$127 \times 192 \mathrm{~mm}(600 \times 600 \mathrm{DPI})$ 


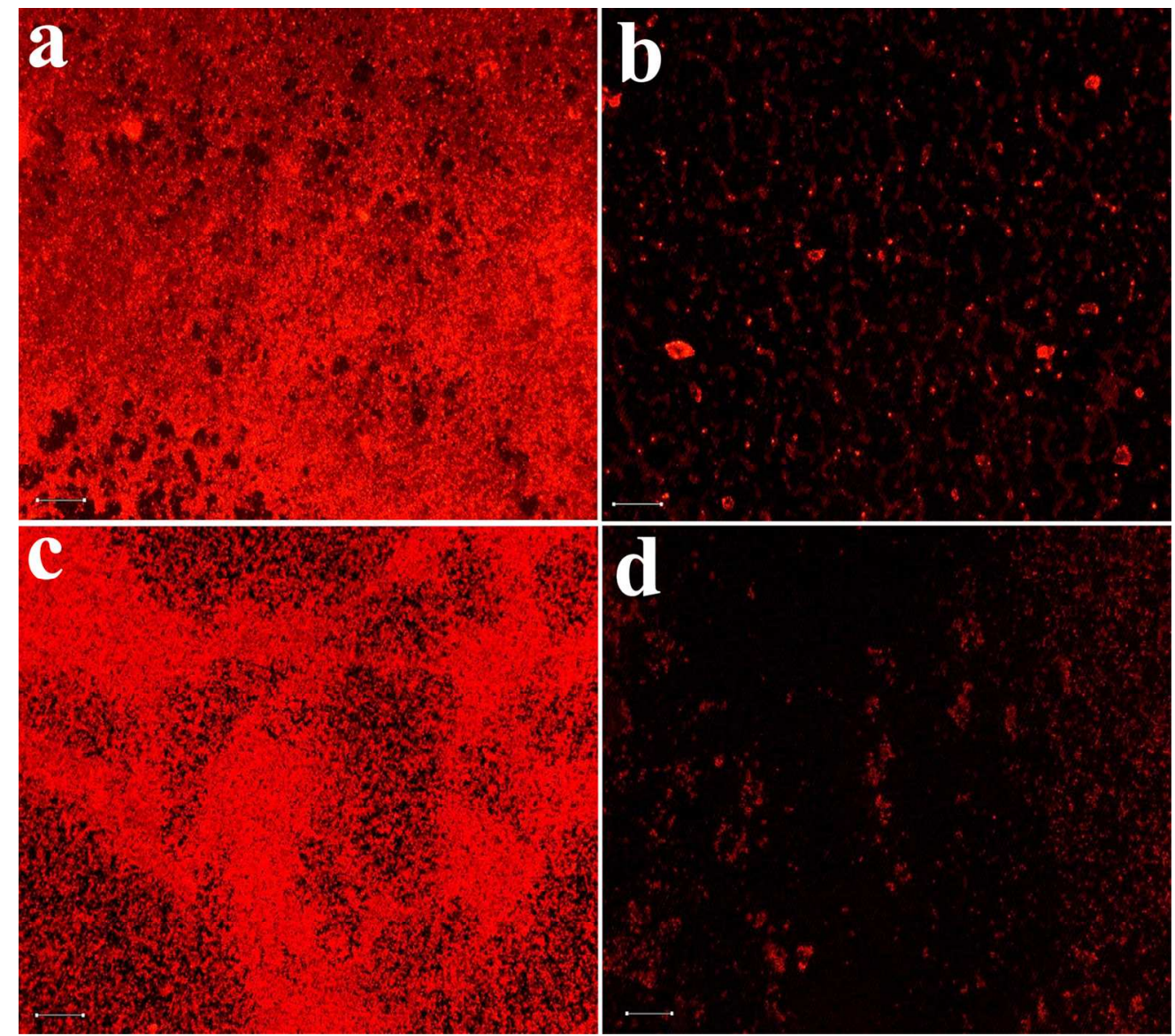

Fig. 6. Congo red stained fluorescence microscope images of biofilm. The biofilm was treated for $24 \mathrm{~h}$ either with $200 \mu \mathrm{g} \mathrm{mL}-1$ Bacoside A or $1 \%$ DMSO as control and then the biofilm matrix was stained with $1 \%$ Congo red. (a) Control and (b) treated biofilm of S. aureus MTCC 96; (c) Control and (d) treated biofilm of P. aeruginosa MTCC 2488. Scale bar represents $25 \mu \mathrm{m}$.

Fig. 6.

$166 \times 148 \mathrm{~mm}(300 \times 300 \mathrm{DPI})$ 

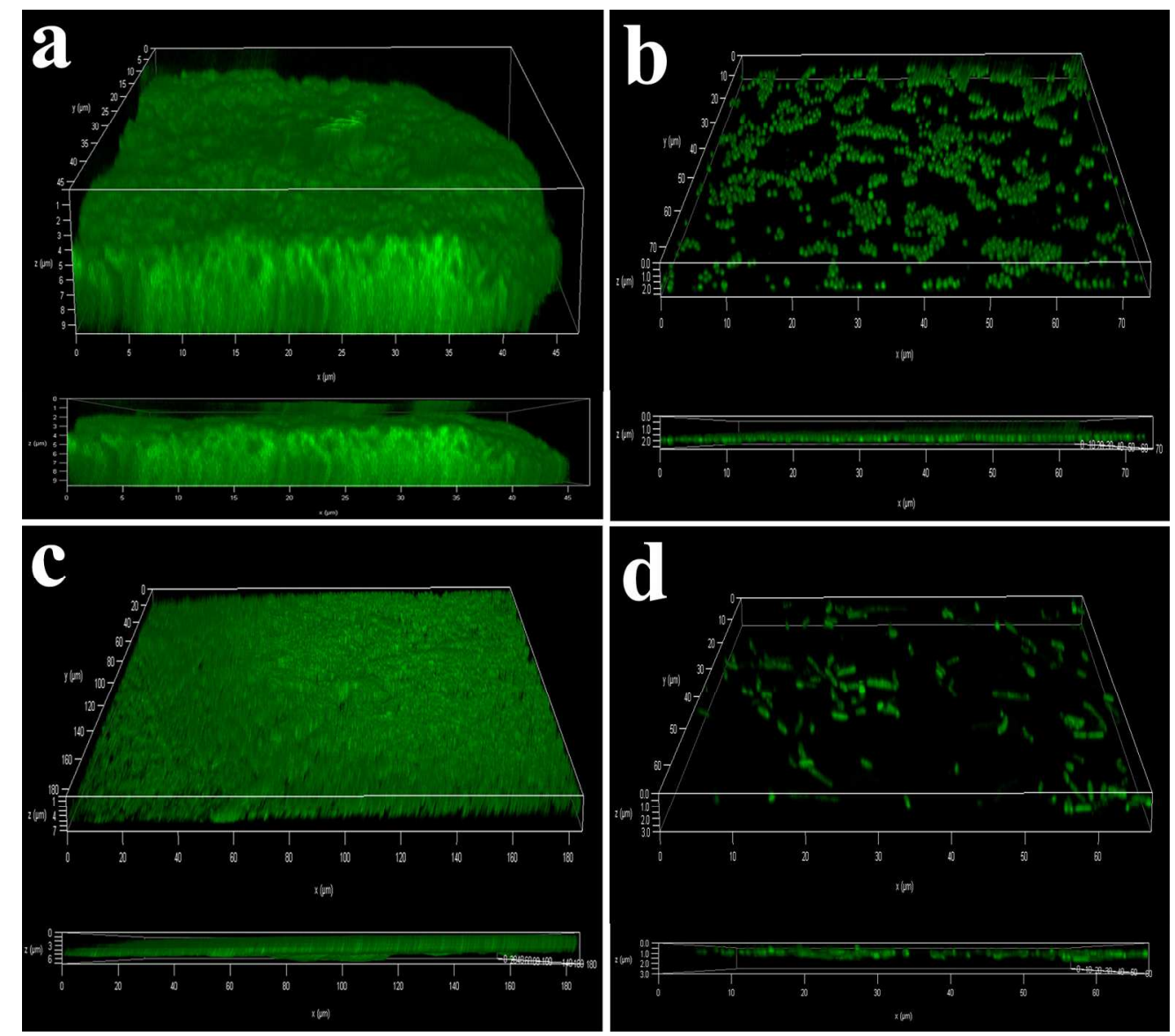

Fig. 7. CLSM of bacterial biofilm before and after Bacoside A treatment. The developed biofilm was treated for $24 \mathrm{~h}$ with $200 \mu \mathrm{g} \mathrm{mL}-1$ Bacoside A or $1 \%$ DMSO as control and then the biofilm matrix was stained with $1 \%$ Congo red for CLSM image analysis. (a) Control and (b) treated biofilm of S. aureus MTCC 96; (c) Control and (d) treated biofilm of P. aeruginosa MTCC 2488. All four images have two separate viewsoblique 3D view (shown in upper part) and vertical view (shown in lower part).

Fig. 7.

$166 \times 148 \mathrm{~mm}(300 \times 300$ DPI) 